\title{
Comunicação, cibercultura e cognição mediadas pela interatividade
}

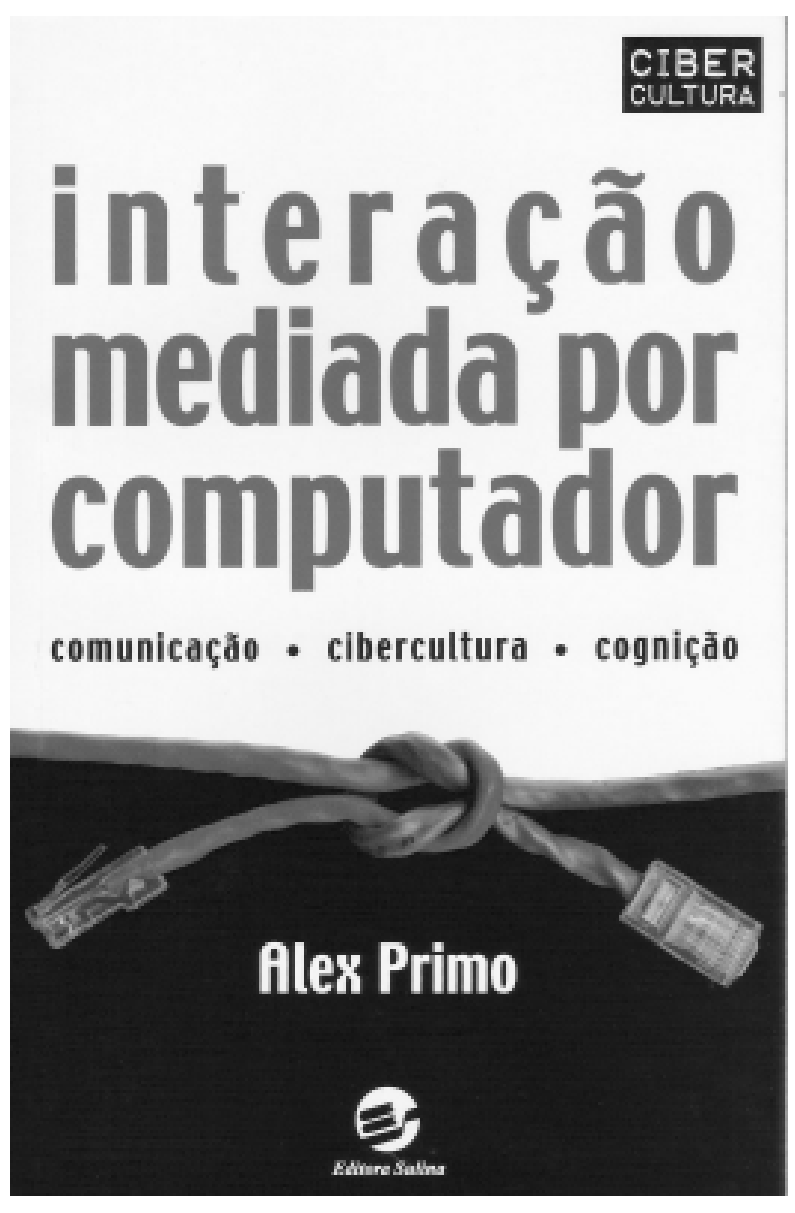

PRIMO, Alex. Interação mediada por computador. Porto Alegre: Sulina, 2007. 240 p.
Ao propor o tema título do livro "Interação mediada por computador" (Editora Sulina, 2007), o autor Alex Primo nos viabiliza uma das reflexões mais caras para os estudos da cibercultura e também para áreas como educação e sociologia. Se estamos em um contexto de rede, conforme Castells (Castells, 2002), este cenário presume interações como raiz do sistema e, portanto, torna-se fundamental a investigação proposta por Primo. O livro é resultado da tese de doutorado do autor, defendida em 2003, na Faculdade de Educação da Universidade Federal do Rio Grande do Sul e premiada pela INTERCOM ${ }^{1}$ e SBIE 2 .

Logo na introdução o autor reforça que a busca pelo entendimento do processo de interatividade não será vista de maneira superficial. A questão que se impõe é: desde a teoria inicial da matemática da comunicação, vista da perspectiva dos engenheiros Shannon e Weaver (Shannon e Weaver, 1962), as mudanças nos meios alteraram também o ponto de vista sobre o processo. A simplicidade do modelo emissor-receptor foi conveniente para explicar de maneira preliminar uma conversa telefônica. Não consegue adentrar, porém, na complexidade que envolve as relações de trocas de informações em redes de comunicação, como as que possuímos hoje. Em primeiro lugar, não há um projétil (apelido dado à teoria) que vá de um lado a outro do campo de comunicação. A troca envolve um complexo sistema de interpretações e socializações e, por isso, o trabalho se aproxima também do campo da educação. Em um segundo momento histórico, o modelo de Shannon e Weaver foi aplicado para as audiências massivas de rádio e de televisão. Em um primeiro olhar também parecia fácil descrever o ambiente com o binômio emissor-receptor, mas a revisão mostrou que há mais complexidade em qualquer processo de comunicação.

Foi através da transformação do computador pessoal em eletrodoméstico, juntamente com consoles de games e outros artefatos responsáveis pela digitalização da informação no cotidiano (Negroponte, 1995), que a palavra interatividade começou a se popularizar. Com o uso intensivo, veio também a banalização do termo. Hoje, ele é usado para agregar valor a qualquer produto que, uma vez sendo interativo, terá necessariamente maior valor percebido. Esse discurso se expande desde um vendedor de eletrodomésticos até diálogos na academia.

$\mathrm{O}$ autor explica que processos aparentemente tidos como interativos, a exemplo da navegação em sites na Web, não necessariamente são dotados de possibilidade de diálogo entre as partes. Primo mostra que normalmente um webdesigner estipula o caminho de links que o internauta, ou interagente, como a obra sugere, vai percorrer. A trajetória pode conter escolhas, mas não necessariamente uma nova proposta de conteúdo. O processo descreve mais uma reação do que uma interação e esta é

\author{
Eduardo Campos Pellanda \\ PUCRS \\ iponline@pucrs.br
}


uma das tônicas do livro. Tratando da raiz do problema é possível repensar a aplicação nos objetos cotidianos.

Uma das questões que Primo estipula no início da debate é a questão da mediação na conversação. Recorre a Thompson (Thompson, 1998) para auxiliar na classificação dos tipos de interação. Um dos pressupostos básicos da interação mediada é que certamente será diferente da face a face. Segue-se uma discussão sobre os meios em si, da TV interativa ao computador, mostrando como as alterações do meio estão conectadas com o tipo de interação. Isso leva também a um discurso tecnicista e mercadológico, que Primo fez questão de abordar. A fuga intencional dessa perspectiva para uma direção mais profunda sobre o tema, leva o autor a uma prévia abordagem e à descrição sobre o tema. Este é um dos aspectos mais importantes da obra em um universo onde as avaliações a respeito da interatividade sempre recaem sobre necessidades do mercado.

Uma outra discussão chave do livro volta-se a alternativas para a explicação de todo o processo de conversação. A perspectiva sistêmica foi fundamentada principalmente pela ótica biológica, de Humberto Maturana e Francisco Varela, e apoiada pela questão da complexidade de Edgar Morin e da teoria dos sistemas de Ludwig Von Bertalanffy. De acordo com esse pensamento, seres vivos estão dentro de um sistema onde a comunicação é o fator de sobrevivência. Se pensarmos nas células de câncer, vemos superficialmente que elas se reproduzem de maneira caótica devido a uma falta de comunicação com as demais células sadias do sistema. Ao contrário do sistema envolvendo somente máquinas, a provocação e o desequilíbrio são fundamentais para que todo o processo se alimente. Neste momento, discute-se a questão da conversação como um processo envolvendo várias dimensões e não somente uma bidimensionalidade.

Um aspecto interessante na questão da comunicação à luz de Maturana e Varela é que as interações se dão de maneira intensamente recíprocas e podem ser descritas como acoplamentos sociais. Primo conecta sua reflexão, nesse momento, ao pensamento de Piaget para tentar explicar a questão cognitiva intrínseca ao processo. A cooperação prevê operações realizadas em grupo, onde cada indivíduo estimula e é estimulado pelo sistema.

Depois das conversações, Primo retorna à questão da interação reativa. Isso se deve à extensão como este tipo de interatividade acontece no cotidiano. Várias interações homem-máquina são feitas dessa forma. A máquina mais primitivamente vem de um outro ser humano que a programou. Assim, o diálogo acontece de maneira indireta, e não bidirecional como uma conversação. Mas é por esse motivo que torna-se tão complexo. Como projetar interfaces para softwares ou páginas Web sem ter a resposta instantânea do usuário? Esta é uma das questões que perturbam todo o indivíduo que precisa propor uma interação reativa. A mediação das informações se torna mais complexa e Primo certamente tem espaço nesse ponto para aprofundar sua obra, visto que é im- possível estancar a questão.

Depois de cruzar com competência, amparado pela perspectiva da complexidade, autores de diversas áreas, Primo conclui que cada pequeno encerramento de etapa do trabalho o levou para mais questões. Isso se dá porque a interação como troca comunicacional é talvez um dos temas mais complexos a ser estudado. Como efeito, só o estudo complexo que não descarta processos biológicos, midiáticos, sociais, cognitivos e até comerciais, está qualificado ao aprofundamento da questão. Talvez por este motivo, ao ser questionado pelo pesquisador Juremir Machado da Silva, em um programa na UNITV de Porto Alegre, sobre o que é interatividade, Alex Primo tenha respondido: não sei! É uma das áreas em que o bordão "quanto mais de se estuda menos se sabe" é muito bem aplicado. Modéstia demasiada de Primo que se tornou um dos pesquisadores mais citados na academia nesse tema, justamente por ter se debruçado sobre o assunto, que além de complexo, implica reestruturar alicerces muito bem sedimentados, devido ao tempo que envolve questões a respeito as teorias da informação e da comunicação. Ao afirmar que "comunicar não é sinônimo de transmitir" e "aprender não é receber", Primo mostra, amparado por uma obra profunda, que os novos meios não só trazem outros conteúdos, mas nos ajudam a desequilibrar o status quo mamecos

\section{NOTAS}

1. Sociedade Brasileira de Estudos Interdisciplinares de Comunicação.

2. Sociedade Brasileira de Informática na Educação.

\section{REFERÊNCIAS}

CASTELLS, Manuel. A Sociedade em Rede: a era da informação: economia, sociedade e cultura. Vol. 1. São Paulo; Paz e Terra, 2002.

THOMPSON, John B, A mídia e a modernidade: uma teoria social da mídia. Petrópolis: Vozes, 1998.

SHANNON, C; WEAVER, W. The mathematical theory of communication. Urbana: University of Ilinois, 1962. 